\title{
Implication of atrial size and function in adults with repaired Tetralogy of Fallot and the effect of treatment by ramipril: the APPROPRIATE randomised trial
}

\author{
Beatrice Bonello ${ }^{1,2^{*}}$, Anselm Uebing ${ }^{3}$, Wei $\mathrm{Li}^{3}$, Gerhard Diller ${ }^{3}$, Michael Gatzoulis ${ }^{3,4}$, Sonya V Babu-Narayan ${ }^{2,4}$ \\ From 16th Annual SCMR Scientific Sessions \\ San Francisco, CA, USA. 31 January - 3 February 2013
}

\section{Background}

Background: Patients with repaired tetralogy of Fallot (rtoF) are at risk of supra-ventricular tachycardia due to atrial dilatation. To date, the impact of atrial size and function has been poorly studied in this population. Angiotensin-converting enzyme (ACE ) inhibitor are known for their beneficial effects on atrial and ventricular remodelling in patients with cardiomyopathy. A previous study (APPROPRIATE study) has demonstrated their beneficial effect on ventricular longitudinal contraction in patients with rtoF. We aimed to study first the impact atria volume and function and second, the effect of ACE inhibitor ramipril in adults with rtoF.

\section{Methods}

Methods: We studied prospectively 61 patients with rtoF from the APPROPRIATE study cohort (median age 29.5 [interquartile range 22-38] years). A double-blinded, placebo-controlled study of 6 months of ramipril was performed. All patients underwent cardiac magnetic resonance imaging (CMR) with both atria and ventricle volume and function measurements, echocardiography, neurohormonal analysis, and objective cardiopulmonary testing at baseline and follow-up. Values are expressed as median [interquartile range].

\section{Results}

Results: At baseline, all patients were in sinus rhythm. Right atrium (RA) maximal area index was 13.7 [12.2-15.2] $\mathrm{cm}^{2} / \mathrm{m}^{2}$. Right ventricle (RV) end-diastolic volume index was $\left(129[109-144] \mathrm{ml} / \mathrm{m}^{2}\right)$ and $\mathrm{RV}$ ejection fraction was 53 [47-49]. It was correlated with age $(\mathrm{r}=0.56, \mathrm{p}<0.0001), \mathrm{RV}$ end diastolic volume index $(\mathrm{r}=0.25, \mathrm{p}=0.04)$, BNP $(\mathrm{r}=0.4, \mathrm{p}=0.0007)$, inversely correlate with right ventricle (RV) ejection fraction $(r=-0.26$, $\mathrm{p}=0.04$ ). LA size and volume were normal and not correlated with any parameter, probably because there was no associated left heart disease and all our studied patients had normal left ventricle volume and ejection fraction. After 6 months of treatment, no arrhythmia occurred. In the ramipril group, LA maximal volume decreased $(p=0.01)$, anterior septum excursion movement increased, BNP level decreased $(\mathrm{p}=0.0004)$ compared to the placebo group.

\section{Conclusions}

Conclusions: RA size was a marker of RV dilatation and systolic dysfunction. Ramipril appears to have beneficial action on left heart with atrial remodelling in patients with rtoF. However ramipril had no effect on the right heart. Further studies with longer follow-up and larger group are needed.

\section{Funding}

British Heart Foundation Fellowship (SVB-N).

French Federation of Cardiology (BB).

Unrestricted Actelion educational grant (GD).

The study was supported by the NIHR Cardiovascular Biomedical Research Unit of Royal Brompton and Harefield NHS Foundation Trust and Imperial College London.

${ }^{1}$ Congenital Heart Diseases, CHU Timone enfants, Marseille, France Full list of author information is available at the end of the article 


\section{Author details}

${ }^{1}$ Congenital Heart Diseases, CHU Timone enfants, Marseille, France. ${ }^{2} \mathrm{CMR}$ Unit, Royal Brompton Hospital, London, UK. ${ }^{3}$ Adults Congenital Heart Disease, Royal Brompton Hospital, London, UK. ${ }^{4}$ Imperial College, Londoon, UK.

Published: 30 January 2013

doi:10.1186/1532-429X-15-S1-E93

Cite this article as: Bonello et al: Implication of atrial size and function in adults with repaired Tetralogy of Fallot and the effect of treatment by ramipril: the APPROPRIATE randomised trial. Journal of Cardiovascular Magnetic Resonance 2013 15(Suppl 1):E93.

Submit your next manuscript to BioMed Central and take full advantage of:

- Convenient online submission

- Thorough peer review

- No space constraints or color figure charges

- Immediate publication on acceptance

- Inclusion in PubMed, CAS, Scopus and Google Scholar

- Research which is freely available for redistribution

Submit your manuscript at www.biomedcentral.com/submit
C Biomed Central 